\title{
СЛОЖНОСТИ ПЕРЕВОДА АЛЛЕГОРИЙ ФРАНСУА РАБЛЕ В РОМАНЕ «ГАРГАНТЮА И ПАНТАГРЮЭЛЬ»
}

\section{DIFFICULTIES IN TRANSLATING ALLEGORIES BY FRANCOIS RABELAIS IN THE NOVEL "GARGANTUA AND PANTAGRUEL"}

\section{O. Borisova}

Summary: The article examines the Difficulties in translating allegories by Francois Rabelais in the novel "Gargantua and Pantagruel".

The research material was the work of F. Rabelais "Gargantua and Pantagruel". The research methods were the analysis of literary sources on the topic of research, linguistic and historical and cultural analysis of a work of art.

It is noted that the use of allegories in the culture of the Middle Ages and the early Renaissance was an integral part of literature. The features of the novel by $F$. Rabelais are presented. The sources of the comic, realized through allegories based on associative links of enumeration of signs / characteristics (verbal image) and truthful description (real concept / object), are characterized. According to the results of the study, it was concluded that the difficulties of translating this work are due to the fact that the object of the comic is not so much objects, but abstract concepts - the national language, its laws and cultural stratification, genre canons and characters. Adequate translation requires a translator to have some experience, background knowledge of a historical, cultural and social nature, as well as an understanding of the context.

Keywords: metaphor, allegory, François Rabelais, "Gargantua and Pantagruel".

\author{
Борисова Оксана Владимировна \\ старший преподаватель, Финансовый университет \\ при Правительстве Российской Федерации \\ 63borxeni@rambler.ru
}

Аннотация: В статье рассматриваются Сложности перевода аллегорий Франсуа Рабле в романе «Гаргантюа и Пантагрюэль».

Материалом исследования послужило произведение Ф. Рабле «Гаргантюа и Пантагрюэль». Методами исследования выступили анализ литературных источников по теме исследования, лингвистический и историко-культурологический анализ художественного произведения.

Отмечено, что использование аллегорий в культуре средних веков и раннего Возрождения являлось неотъемлемым направлением литературы. Представлены особенности романа Ф. Рабле. Охарактеризованы источники комизма, реализованного посредством аллегорий, основанных на ассоциативных связях перечисления признаков / характеристик (вербального образа) и правдивого описания (реального понятия / объекта). По итогам исследования сделан вывод 0 том, что сложности перевода данного произведения обусловлены тем, что объектом комизма выступают не столько предметы, а абстрактные понятия - национальный язык, его законы и культурная стратификация, жанровые каноны и персонажи. Для адекватного перевода переводчику требуется определенный опыт, фоновые знания исторического, культурологического и социального характера, а также понимание контекста.

Ключевые слова: метафора, аллегория, Франсуа Рабле, «Гаргантюа и Пантагрюэль».

\section{Введение}

$\mathrm{P}$ оман Ф. Рабле «Гаргантюа и Пантагруэль» представляет собой пространство народной смеховой культуры. В русскую культуру автор не вошел ввиду сформированности среди лингвистов феномена «непереводимости Рабле» на иностранные языки, поскольку требует комментариев и интерпретации. Тем не менее частичный перевод отрывков романа проводился с 17 века, когда начал формироваться историко-аллегорический метод истолкования Ф. Рабле.

Перевод Н.М. Любимова 1973 г. позволил передать посредством адекватного перевода фамильярность, непринужденность и глубину смеховой образности Ф. Рабле. Отличительными особенностями романа целесообразно назвать вольность смеха, обусловленная сформированным высокой степенью идеологического сознания, стремление преодолеть скрытый догматизм, обрамленный традициями, народно-праздничными формами.

М.М. Бахтин называл Ф. Рабле ключом к пониманию народной смеховой культуры последних трех веков, что можно обосновать следующими тенденциями в литературе 16 века:

- формирование литературно-языкового сознания эпохи посредством пересечения рубежа языков, диалектов, наречий, жаргонов;

- языки стали представляться как конкретные, социальные, обусловленные системой оценок, жизненной практикой и классовой борьбой, что вовлекло каждое понятие, явление, предмет и образ в напряженную идеологическую борьбу;

- литературно-языковое сознание оказалось на рубеже борьбы.

В связи с этим в эпоху Ф. Рабле предметный и языко- 
вой мир обогащался как новыми словами, заимствованными из итальянского, греческого, латинского, неологизмами, так и сохранял большое количество архаизмов.

\section{Материалы и методы исследования}

Материалом исследования послужило произведение Ф. Рабле «Гаргантюа и Пантагрюэль».

Методами исследования выступили анализ литературных источников по теме исследования, лингвистический и историко-культурологический анализ художественного произведения.

\section{Результаты исследования и их обсужление}

В исследованиях М.П. Брандеса, Г. Михеля, А.А. Потебни, Э.Г. Ризеля, В. Фляйшера, Е.И. Шендельса аллегория рассматривается как подвид метафоры. Современные лингвисты Н.Д. Арутюнова, Л.М. Алексеева, М.Г. Мелентьева, Дж. Миллер, М.В. Никитин, Г.Н. Скляревская, В.Н. Телия, М. Блэк, М. Джонсон, Д. Дэвидсон, Дж. Лакофф, М. Тернер, Ж. Фоконье представляют метафору с точки зрения ее порождения и представления в художественном произведении. При этом аллегория рассматривается только как стилистическая фигура [5].

В работах И.В. Арнольда, И.Б. Голуба, Н.Н. Гончаровой, Ф. Растье, П. Фонтанье аллегория определяется как самостоятельное явление ввиду иносказательности [6].

На основе толкования понятий метафоры и аллегории можно сделать вывод о том, что метафора отражает признак или комплекс признаков имманентного характера. Задачей же аллегории является приписывание предмету отвлеченного и недостаточно освоенного понятия посредством более конкретного и доступного.

По сути, аллегория является и образом, и значением, соответственно, ее можно обозначить как слияние нескольких метафор. Если же рассматривать аллегорию в узком смысле, то она представляется как сложная и полная метафора, в которой отсутствует четкое указание на ее значение [1]. Тем не менее в данной позиции не учитываются различия в способе порождения как процессе познания двойных смыслов.

В лексикологическом словаре акцентируется внимание на том, что метафора возникает на основе сходных или контрастных черт, отношений предметов и явлений бытия, существуя вне сознания человека. Процессу же аллегоризации подвергаются только абстрактные понятия [2].

Целесообразно заключить, что процесс порождения аллегории основан на ассоциативных связях. При этом в аллегории имеются два плана: образно-предметный используется только одним человеком в его сознании, который и является автором, и смысловой, характерный для общепринятых аллегорий. Соответственно, метафора носит более поверхностный общий характер, тогда как аллегория находится в сознании конкретного человека.

Реализация двойного смысла аллегории осуществляется на уровне текста как отражения действительности, единицы коммуникации, организованную закрытую цепочку предложений, представляющих собой единое высказывание [3].

Таким образом, для понимания аллегории субъекту необходимо иметь определенный опыт, фоновые знания исторического, культурологического и социального характера, а также понимание контекста, при отсутствии которого взаимодействие явного и скрытого смыслов не будет реализовано.

Исходя из вышеизложенного, аллегория относится к числу феноменов, понимание которых требует определенных знаний и опыта. Соответственно, перевод аллегорий может вызывать значительные сложности.

Использование аллегорий в культуре средних веков и раннего Возрождения являлось неотъемлемым направлением литературы.

Рассмотрим особенности аллегоризации в романе Ф. Рабле.

Обратить внимание стоит на алькофрибасовы прологи, где автор проводит смеховую игру с канонами и приемами средневековой словесности, указывая на сугубо средневековое понимание словесности и книги. Объектом пародии в данном случае выступают национальный язык, его законы и культурная стратификация, жанровые каноны и персонажи. При этом языковая игра в целом выступает как проявление свободы духа, характерного для эпохи Ренессанса.

Языку Ф. Рабле свойственны нарочитая плебейская грубоватость, что проявляется в родстве с народом: автор изображает быт плебеев, наслаждаются жизнью, показывает, что некоторые низы заслуживают лучшей участи, тогда как представители высших классов подвергаются гонениям, занимаются презренными профессиями.

Ассоциативные связи, на которых построены аллегории в романе, представлены автором на фоне вдохновения, сравнения и наложения на собственную модель видения. К примеру, примечательным в данном случае является описание Телемского аббатства, в основе идеи которого король Франции Франсуа Первый, начавший строительство замков после возвращения из плена. В 
результате получено наложение описания королевского замка в Мадриде на замок Шамбор и Телемское аббатсво.

Телемская обитель для монаха Жана автор описывается как анархическая коммуна, в которой жизнь подчинена одному правилу - «делай, что хочешь», то есть проповедуется «собственная добрая воля и хотение» - «Ибо нас искони влечет к запретному, и мы жаждем того, в чем нам отказано», резюмирует автор романа [7]. Ф. Рабле приводит аналогию со свободными порядочными людьми, главным отличием которых является честь и достоинство, наделение «побудительной силой» [7]. По словам автора, только давление извне способно изменить поведение человека, поскольку только тогда человек начинает стремиться «сбросить ярмо рабства». Девиз «Fay ce que vouldras» напоминает фразу Святого Августа «Dilige et quod uis facit». Связь девиза Телемитов и девиза Гаргантюа позволяет восстановить целиком слова Святого Августа, а также определение свободы, которое дает Цицерон «Qu'est-ce que la liberté? le pouvoir de vivre comme on veut» $[14$, p.488].

Стоит обратить внимание на аллегорический ряд финансовой системы, в частности, «социальный ценз» для «монахов». Рассмотрим скрытый смысл аллегории. В монахи не принимали представителей государственной бюрократии: «официалов всех мастей», клерков, судей, «скрягам - ростовщикам», скупцам. Для монахов несвойственно зарабатывание денег, поэтому создавая обитель, Гаргантюа позаботился о ее содержании, даровав телемитам гарантированную поземельную ренту [12, с.116]. Тем самым было создано общество потребителей.

Следующий процесс предметно-понятийной аллегоризации связан с «коммерческими расчетами», то есть кредитными обязательствами. Ф. Рабле описывает систему, в которой деньги как способ расчета и продукт финансовых взаимоотношений становятся инструментом и ресурсом власти государства, тем самым государство становится монополией, а деньги превращаются в «оружие». На фоне подобной картины событий Ф. Рабле описывает остров «длиннополых и крючкоруких» апедевтов, которых посетил Пантагрюэль. Местный житель Загребай «стрижет кошельки», будучи проводников на острове, он показывал жилища в форме давильного пресса, апедевтов, которые давили в прессе «саженцы» (замки, парки, леса и т.д.). Продуктом пресса становилось «питьевое золото». Так, становится понятным, что саженцы на языке автора это денежные ресурсы и имущество (пожертвования, сбережения, любые доходы и т.д.), а детали пресса имеют собственное значение: «Винт пресса назывался приход; его лохань - расход; большая гайка - государство; днище - недоимка; барабан - застой (неоплаченные векселя); поршни - списать; тиски - квитанции; гребни - доверенность; воронка - баланс....» [7].
Таким образом, Ф. Рабле представил целую финансовую систему как машину исполнения и администрирования, благодаря коммерческим механизмам которой обязательства и обещания превращаются в долг.

Следует отметить, что в эпоху европейского Ренессанса шел активный процесс формирования абсолютных монархий, что требовало понимания государственной финансовой политики с точки зрения научного знания. Поэтому важными направлениями государственной политики становятся налоговые обязательства, источники и способы получения доходов [4].

Исходя из вышеизложенного, в аллегоризме Ф. Рабле можно проследить два источника комизма:

- вербальный образ, проявляющийся в перечислении признаков / характеристик явления / понятия;

- правдивое описание образа / предмета с возможным небольшим преувеличением.

Примером также может служить Диоген, который крутит свою знаменитую бочку, чтобы не оставаться без дела во время военных приготовлений (Diogènt, pour ne pas rester inactif au milieu des préparatifs militaires des Corinthiens, roule son tonneau: déployant ses bras, le tournant, virait, brouillait, hersait, versait, renversait, nattait, grattait, flattait, battait, boutait, buttait, etc. (Prologue du Tiers livre) $[16$, p.72]).

Таким образом, сложности перевода романа Ф. Рабле обусловлены:

- спецификой государственной системы в целом;

- способностью переводчика выявлять ассоциативные связи между вербальным образом и правдивым его описанием;

- необходимостью определенного объема знаний об исторических и культурных особенностях периода написания романа, включая периоды до и после его написания;

- зависимостью от понимания контекста с целью обнаружения явного и скрытого смыслов.

\section{Зак^ючение}

Роман Ф. Рабле «Гаргантюа и Пантагрюэль» является достаточно ярким и выразительным представителем культуры Ренессанса Франции, в котором отражено не только проявление буржуазных сил и государственной системы в целом, но и их буйство, становление, формирование.

В произведении представлена взаимосвязь литературы широких масс народа с фольклорными корнями и новых, литературных элементов. При этом способ изложения направлен на достижение народного понимания идеи и смыслов. Ввиду этого в романе присутствует 
комизм, реализованный посредством аллегорий, основанных на ассоциативных связях перечисления признаков / характеристик (вербального образа) и правдивого описания (реального понятия / объекта). Сложности перевода данного произведения обусловлены тем, что объектом комизма выступают не столько предметы, а абстрактные понятия - национальный язык, его законы и культурная стратификация, жанровые каноны и персонажи. Для адекватного перевода переводчику требуется определенный опыт, фоновые знания исторического, культурологического и социального характера, а также понимание контекста.

\section{ЛИТЕРАТУРА}

1. Багаева 0.В. Актуальность ассоциативного подхода при рассмотрении двойных смыслов немецких аллегорических выражений / 0.B. Багаева // Культура и текст. - 2005. - №10. - URL: https://cyberleninka.ru/article/n/aktualnost-assotsiativnogo-podhoda-pri-rasmotrenii-dvoynyh-smyslov-nemetskihallegoricheskih-vyrazheniy (дата обращения: 15.02.2021).

2. Воронушкина 0.В. Аллегория и символ как средства актуализации скрытых смыслов / 0.В. Воронушкина // Вестник ВятГУ. - 2016. - №4. - URL: https:// cyberleninka.ru/article/n/allegoriya-i-simvol-kak-sredstva-aktualizatsii-skrytyh-smyslov (дата обращения: 15.02.2021).

3. Кочековская Н.А. Аллегория как режим темпоральности в гуманитаристике XX в.: анахронизм как культурная практика / / Н.A. Кочековская / Шаги/Steps - 2018. - №3-4. - URL: https://cyberleninka.ru/article/n/allegoriya-kak-rezhim-temporalnosti-v-gumanitaristike-hh-v-anahronizm-kakkulturnaya-praktika (дата обращения: 19.02.2021).

4. Кудрин А.Л., Афанасьев М.П. Государственные финансы Ренессанса: Карафа - Ортис - Боден / А.Л. Кудрин, М. П. Афанасьев. - М.: Магистр Инфра-М, 2015. - 144 c.

5. Масленникова А.А. Скрытые смыслы и их лингвистическая интерпретация (на материале русского и английского языков): дис. ... д-ра филол. наук / А.А. Масленникова. - СПб.: Питер, 1999. - 284 с.

6. Овсянникова Е.В. Основные функции имплицитных смыслов в высказываниях и текстах: на материале англоязычной прозы: автореф. дис. ... канд. филол. наук / Е.В. Овсянникова. - ППб.: Питер, 1993. - 25 с.

7. Рабле Ф. Гаргантюа и Пантагрюэль / Ф. Рабле. - СПб.: Азбука, 2015. - 640 с.

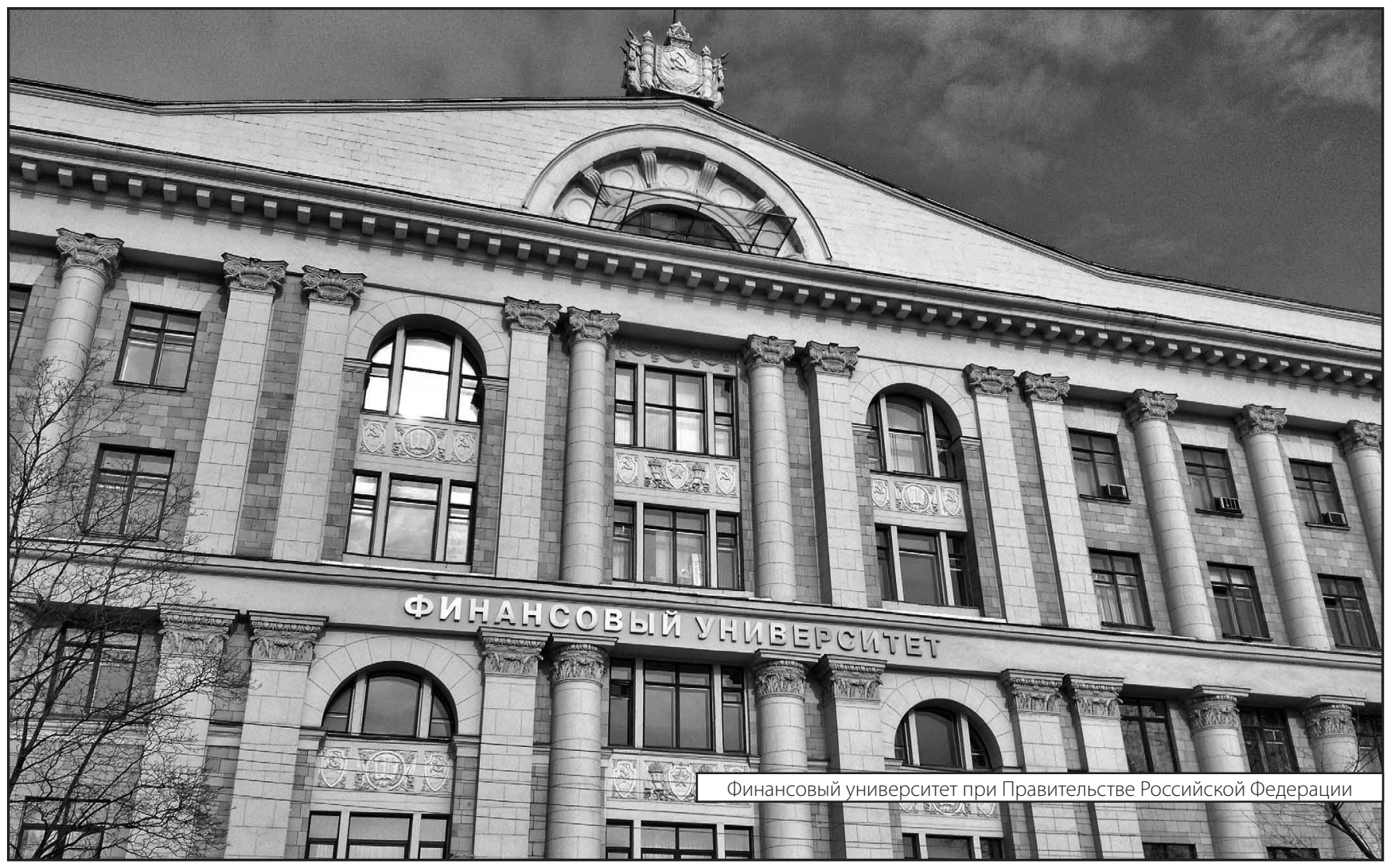

